\title{
Przedsiębiorstwo w społeczeństwie informacyjnym
}

https://doi.org/10.33141/po.2005.03.10

\section{Wojciech Jarecki}

Terminem coraz częściej spotykanym w literaturze ekonomicznej jest „społeczeństwo informacyjne”. Za Krzysztofkiem i Szczepańskim można przyjąć, że jest to „społeczeństwo, w którym informacja jest intensywnie wykorzystywana w życiu ekonomicznym, społecznym, kulturalnym i politycznym; to społeczeństwo, które posiada bogate środki komunikacji i przetwarzania informacji, będące podstawą tworzenia większości dochodu narodowego oraz zapewniające źródło utrzymania większości ludzi" (Krzysztofek, Szczepański, 2002, s. 170*)). Jak widać w powyższej definicji, pojęcie społeczeństwa informacyjnego związane jest $\mathrm{z}$ przepływem informacji i rozwojem technologicznym związanym z komunikacją i informatyką.

Podstawą wzrostu gospodarczego są dobrze funkcjonujące przedsiębiorstwa. Osiągają one określone przychody, ponosząc wcześniej koszty. Na wzrost przychodów i obniżenie kosztów działalności wpływać może szybki przepływ informacji. Dla przedsiębiorstwa istotny jest przepływ informacji między nim a klientami, administracją państwową i innymi przedsiębiorstwami.

W artykule dokonano próby oceny stanu zaawansowania rozwoju społeczeństwa informacyjnego w Polsce, na tle innych krajów europejskich, i funkcjonowania w nim przedsiębiorstw. Celem analizy jest wskazanie, dla polityki gospodarczej państwa, słabych stron w szeroko rozumianym zakresie komunikacyjno-informatycznym, co ułatwiłoby kierunki ewentualnej interwencji, szczególnie dla wsparcia przedsiębiorstw.

Miary oceny stanu rozwoju społeczeństwa informacyjnego, zawarte w artykule, zostały utworzone na bazie danych zaprezentowanych w Eurostacie. Miarami tymi, określonymi przez Eurostat jako miary strukturalne, są: odsetek gospodarstw domowych i przedsiębiorstw mających dostęp do internetu, wydatki na zakup technologii informatycznych i komunikacyjnych w \% PKB, udział sprzedaży internetowej w całości sprzedaży, stopień wykorzystania internetu przez przedsiębiorstwa i w kontaktach $\mathrm{z}$ administracja państwową, liczba zainstalowanych połączeń szerokopasmowych.

Pierwszą miarą, istotną również dla przedsiębiorstw, jest odsetek gospodarstw domowych majacych dostęp do internetu. Dzięki temu dostępowi gospodarstwa domowe mogą kontaktować się z przedsiębiorstwami i administracją publiczną, poszukiwać pracy, robić zakupy itd. Pożądany zatem wydaje się powszechny dostęp gospodarstw domowych do internetu. Dane dotyczace tego zagadnienia zestawiono w tabeli 1 .

W latach 2000-2004 we wszystkich analizowanych krajach nastąpił wzrost odsetka gospodarstw domo- wych posiadających dostęp do internetu. Średnio, w 2004 roku, w UE dostęp miało $42 \%$ gospodarstw domowych, z czego najwięcej w Danii (69\%), Niemczech (60\%) i w Wielkiej Brytanii (56\%). Najmniejszy dostęp maja gospodarstwa domowe w Turcji (7\%), na Litwie (12\%) i na Węgrzech (14\%). Polska należy do krajów znajdujących poniżej średniej unijnej (26\%), co jest niekorzystne dla komunikacji przedsiębiorstw z pracobiorcami, będącymi jednocześnie klientami.

Dostęp do internetu jest jednak bardzo potrzebny samym przedsiębiorstwom, szczególnie w warunkach szybkiej globalizacji. Stan dostępu przedstawiono w tabeli 2 .

W latach 2000-2004 wzrastał odsetek przedsiębiorstw mających dostęp do internetu. W 2004 roku w UE wynosił on $89 \%$. Najwięcej przedsiębiorstw ma dostęp do internetu w Danii i Finlandii (po 97\%) oraz Belgii i Szwecji (po 96\%), najmniej na Węgrzech (78\%), w Portugalii $(80 \%)$ i na Litwie $(81 \%)$. Brak jest dokładnych danych za ostatnie lata w Polsce, ale na podstawie porównań z roku 2001 można stwierdzić, że zbliżony jest do średniej unijnej (w $2001 \mathrm{w}$ Polsce wynosił $74,2 \%$ wobec średniej unijnej wynoszącej $70,3 \%)$.

Odnośnie do opisanych tabel (tab. 1 i 2) można zauważyć, że zdecydowanie większy odsetek przedsiębiorstw niż gospodarstw domowych ma dostęp do internetu. Być może celem polityki państwa mógłby być powszechniejszy dostęp do internetu zarówno przedsiębiorstw, jak i gospodarstw domowych i w tym kierunku należałoby oczekiwać ewentualnego wsparcia.

Dostęp do internetu związany jest z potrzebą posiadania komputera i możliwością podłączenia do łącza, za pomocą którego będzie odbywała się transmisja danych. Do komunikacji służy również telefon stacjonarny czy komórkowy i inne tego typu nowocześniejsze urządzenia. W kolejnych dwóch tabelach przedstawiono wydatki $\mathrm{w} \% \mathrm{PKB}$ na technologie informatyczne i komunikacyjne (tabela 3 i 4).

W UE wydatki na technologie informatyczne wyniosły w 2004 roku 2,9\% PKB i nie zmieniły się w ostatnich latach. Z wymienionych krajów najwięcej wydaje się w Szwajcarii (4,2\%), Wielkiej Brytanii $(4,0 \%)$ i Szwecji (3,9\%), najmniej w Turcji (ok. 1\%), Grecji (1,2\%), Hiszpanii (1,5\%). W Polsce w 2004 roku wydano $2,4 \%$ PKB, czyli poniżej średniej unijnej, ale można zaobserwować dosyć dynamiczny przyrost od 2000 roku.

Średnio w dawnej UE na technologie komunikacyjne wydaje się 3,2\% PKB. Z krajów ujętych w tabeli 4 najwięcej wydaje się w krajach słabiej rozwiniętych, a mianowicie w Bułgarii $(8,4 \%)$, na Łotwie $(7,3 \%)$, 
Tab. 1. Odsetek gospodarstw domowych mających dostęp do internetu

\begin{tabular}{|c|c|c|c|c|c|}
\hline Kraj & 2000 & 2001 & 2002 & 2003 & 2004 \\
\hline $\begin{array}{l}\text { Unia Europejska } \\
\text { (25 krajów) }\end{array}$ & - & - & - & - & 42 \\
\hline $\begin{array}{l}\text { Dawna Unia Euro- } \\
\text { pejska (15 krajów) }\end{array}$ & 18,3 & 36,1 & 39 & 44 & 45 \\
\hline Belgia & 20,2 & 34,7 & 40,9 & - & - \\
\hline Czechy & 8 & 11 & 16 & 15 & - \\
\hline Dania & 45,3 & 58,9 & 56 & 64 & 69 \\
\hline Niemcy & 13,6 & 37,9 & 46 & 54 & 60 \\
\hline Estonia & 7 & 9,8 & - & - & 31 \\
\hline Grecja & 5,8 & 11,7 & 12 & 16 & 17 \\
\hline Hiszpania & 9,6 & 23,4 & 17 & 28 & 34 \\
\hline Francja & 12,9 & 26,2 & 23 & 31 & 34 \\
\hline Irlandia & 17,5 & 46,2 & 47,9 & 36 & 40 \\
\hline Włochy & 19,2 & 32,9 & 34 & 42 & 34 \\
\hline Cypr & 14,0 & 20,0 & 24 & 29 & 53 \\
\hline Łotwa & - & 2,3 & 3 & - & 15 \\
\hline Litwa & 2,3 & 3,2 & 4 & 6 & 12 \\
\hline Węgry & 2,6 & - & - & - & 14 \\
\hline Holandia & 46,1 & 58,5 & 58 & 59 & - \\
\hline Austria & 16,9 & 46,2 & 33 & 37 & 45 \\
\hline Polska & 5,1 & 7,7 & 11 & 14 & 26 \\
\hline Portugalia & 8,4 & 23,4 & 16 & 22 & 26 \\
\hline Słowenia & 21 & 24 & - & - & 47 \\
\hline Finlandia & 28,2 & 48,1 & 44 & 47 & 51 \\
\hline Szwecja & 47,5 & 64,3 & 64,2 & - & - \\
\hline Wielka Brytania & 24,4 & 46,5 & 50 & 55 & 56 \\
\hline Norwegia & 52 & 62,2 & - & 60 & - \\
\hline Turcja & - & - & - & - & 7 \\
\hline
\end{tabular}

Źródło:http://europa.eu.int/comm/eurostat/newcronos/suite/ retrieve/de/theme4/infosoc/structur/broad?OutputDir=EJ OutputDir_1969\&clientsessionid=D360CA85303ABFBE603DF35599F5C89C.extraction-anonymous-worker-1\& OutputFile $=$ broad.htm $\&$ OutputMode $=$ U\&OutputMime $=$ text\%252Fhtml\&

w Polsce $(7,2 \%)$ i Rumunii $(6,6 \%)$. Najmniej natomiast w Norwegii $(2,4 \%)$, Francji $(2,5 \%)$ i Irlandii $(2,7 \%)$. Polska należy zatem do krajów o dużych wydatkach na technologie komunikacyjne, co wynika prawdopodobnie $\mathrm{z}$ dotychczasowych, niedużych wydatków w porównaniu z krajami rozwiniętymi.

Rozwój internetu wpłynął również na taką dziedzinę, jak handel. Powstaje coraz więcej przedsiębiorstw sprzedajacych przez internet oraz wzrasta liczba przedsiębiorstw, które wykorzystując dotychczasową sieć, sprzedają również przez internet. Poniżej zostały przedstawione zmiany w procentowym udziale sprzedaży internetowej w całości sprzedaży.

Procentowy udział sprzedaży internetowej w całości sprzedaży wzrasta w większości analizowa-
Tab. 2. Odsetek przedsiębiorstw mających dostęp do internetu

\begin{tabular}{|c|c|c|c|c|c|}
\hline Kraj & 2000 & 2001 & 2002 & 2003 & 2004 \\
\hline $\begin{array}{l}\text { Unia Europejska } \\
\text { (25 krajów) }\end{array}$ & - & - & - & - & 89 \\
\hline $\begin{array}{l}\text { Dawna Unia Euro- } \\
\text { pejska (15 krajów) }\end{array}$ & - & 70,3 & 80 & 88 & 90 \\
\hline Belgia & - & 79 & - & 92 & 96 \\
\hline Czechy & - & - & - & - & 90 \\
\hline Dania & - & 86,6 & 95 & 98 & 97 \\
\hline Niemcy & - & 82,8 & 84 & 95 & 93 \\
\hline Grecja & - & 50,6 & 64 & 87 & - \\
\hline Hiszpania & - & 67,0 & 82 & 84 & 89 \\
\hline Francja & - & 58,0 & - & - & - \\
\hline Irlandia & - & 77,0 & 82,8 & 86 & - \\
\hline Włochy & - & 66 & 74 & 83 & 88 \\
\hline Cypr & 63 & - & - & 88,0 & 84 \\
\hline Łotwa & 45,6 & 45,6 & 50,9 & 60,0 & - \\
\hline Litwa & - & 58,6 & 65,5 & 68,5 & 81 \\
\hline Węgry & - & - & - & - & 78 \\
\hline Holandia & - & 79 & 85 & 86 & 89 \\
\hline Austria & - & 76,5 & 85 & 90 & 94 \\
\hline Polska & 40,4 & $\mathbf{7 4 , 2}$ & - & - & - \\
\hline Portugalia & - & 71,8 & 69 & 71 & 80 \\
\hline Słowenia & 88 & - & - & - & 95 \\
\hline Finlandia & - & 90,8 & 96 & 97 & 97 \\
\hline Szwecja & - & 89,9 & 95 & 95 & 96 \\
\hline Wielka Brytania & - & 63,4 & 74 & 81 & 86 \\
\hline Norwegia & - & 73,2 & 82 & 88 & - \\
\hline
\end{tabular}

Źródło:http://europa.eu.int/comm/eurostat/newcronos/suite/ retrieve/de/theme4/infosoc/structur/broad?OutputDir $=$ EJ OutputDir_1969\&clientsessionid=D360CA85303ABFBE603DF35599F5C89C.extraction-anonymous-worker-1\& OutputFile $=$ broad.htm $\&$ OutputMode $=$ U\&OutputMime $=$ text\%252Fhtml\&

nych krajów. W 2004 roku w krajach dawnej UE sprzedaż internetowa wyniosła średnio 2,3\%. Najwięcej przez internet sprzedaje się w Irlandii $(12,3 \%)$, Danii $(4,4 \%)$ i Niemczech $(2,7 \%)$, najmniej w Norwegii $(0 \%)$, która zanotowała jednocześnie spadek z 2,4\%, w Hiszpanii $(0,4 \%)$, Austrii $(1,0 \%)$ i prawdopodobnie w Grecji. Polska z 1,3\% udziału sprzedaży internetowej w całości sprzedaży nie odbiega w istotny sposób od wielkości sprzedaży w większości krajów europejskich.

Czynnikiem, który w istotny sposób może wpływać na oszczędność czasu pracy, szczególnie w małych przedsiębiorstwach, jest wykorzystanie internetu do komunikacji z administracją publiczną. Zaoszczędzony czas powoduje lepsze wykorzystanie czasu pracy, a tym samym wzrost wydajności. W tabeli 6 zaprezentowano odsetek przedsiębiorstw wykorzystu- 
jących internet do kontaktów $\mathrm{z}$ administracją publiczną.

Odsetek przedsiębiorstw komunikujących się przez internet $\mathrm{z}$ administracją publiczną wynosi w UE 51\%. Największy odsetek przedsiębiorstw kontaktuje się w Szwecji (92\%), Finlandii (91\%), Danii (85\%). Najmniej w Wielkiej Brytanii (33\%), na Cyprze i na Węgrzech $(35 \%)$ oraz w Niemczech (36\%). Polska, z 74\% przedsiębiorstw, plasuje się zdecydowanie powyżej średniej europejskiej, co jest zjawiskiem bardzo korzystnym.

Tab. 3. Wydatki w \% PKB na technologie informatyczne

\begin{tabular}{|c|c|c|c|c|}
\hline Kraj & 2001 & 2002 & 2003 & 2004 \\
\hline $\begin{array}{l}\text { Unia Europejska } \\
\text { ( } 25 \text { krajów) }\end{array}$ & 3,1 & 2,9 & 2,9 & 2,9 \\
\hline $\begin{array}{l}\text { Dawna Unia Europejska } \\
\text { (15 krajów) }\end{array}$ & 3,2 & 3,0 & 3,0 & 2,9 \\
\hline Belgia & 3,4 & 3,1 & 2,9 & 2,9 \\
\hline Czechy & 3,3 & 3,1 & 3,4 & 3,4 \\
\hline Dania & 3,8 & 3,5 & 3,4 & 3,4 \\
\hline Niemcy & 3,3 & 3,0 & 3,0 & 2,9 \\
\hline Estonia & 2,7 & 2,7 & 2,7 & 2,6 \\
\hline Grecja & 1,4 & 1,3 & 1,2 & 1,2 \\
\hline Hiszpania & 1,8 & 1,6 & 1,6 & 1,5 \\
\hline Francja & 3,5 & 3,3 & 3,1 & 3,1 \\
\hline Irlandia & 2,1 & 1,8 & 1,7 & 1,6 \\
\hline Włochy & 2,1 & 2,0 & 1,9 & 1,8 \\
\hline Łotwa & 1,9 & 2,1 & 2,5 & 2,5 \\
\hline Litwa & 1,5 & 1,5 & 1,6 & 1,6 \\
\hline Węgry & 3,0 & 2,6 & 2,8 & 2,8 \\
\hline Holandia & 3,9 & 3,6 & 3,5 & 3,5 \\
\hline Austria & 3,1 & 2,9 & 2,9 & 2,9 \\
\hline Polska & 1,6 & 1,8 & 2,5 & 2,8 \\
\hline Portugalia & 2,2 & 1,9 & 2,0 & 2,0 \\
\hline Słowenia & 1,8 & 2,0 & 2,1 & 2,2 \\
\hline Słowacja & 2,7 & 2,7 & 2,5 & 2,4 \\
\hline Finlandia & 3,5 & 3,4 & 3,4 & 3,4 \\
\hline Szwecja & 4,7 & 4,3 & 4,0 & 3,9 \\
\hline Wielka Brytania & 4,0 & 3,8 & 4,4 & 4,0 \\
\hline Norwegia & 3,5 & 2,8 & 3,1 & 3,4 \\
\hline Szwajcaria & 4,4 & 3,9 & 4,0 & 4,2 \\
\hline Bułgaria & 1,6 & 1,7 & 1,8 & 1,8 \\
\hline Rumunia & 1,0 & 1,3 & 1,7 & 1,8 \\
\hline Turcja & 1,3 & 1,0 & 0,8 & - \\
\hline
\end{tabular}

Źródło:http://europa.eu.int/comm/eurostat/newcronos/suite/ retrieve/de/theme4/infosoc/structur/broad?OutputDir =EJ OutputDir 1969\&clientsessionid = D360CA85303ABFBE603DF35599F5C89C.extraction-anonymous-worker-1\& OutputFile $=$ broad.htm $\&$ OutputMode $=$ U\&OutputMime $=$ text\%252Fhtml\&
Istotnym czynnikiem wpływajacym na szybkość przepływu informacji jest stosowanie połączeń szerokopasmowych.

W lipcu 2004 r. w UE z łącza szerokopasmowego korzystało 6,5\% organizacji, z czego najwięcej w Danii (15,6\%), Holandii (14,7\%), Belgii (14,0\%). Najmniej było w Grecji $(0,2 \%)$, na Słowacji $(0,4 \%)$, w Polsce $(0,5 \%)$ i w Czechach $(0,7 \%)$.

\section{Wnioski}

Polska należy do krajów o niskim dostępie gospodarstw domowych do internetu. Jest to niekorzystne

Tab. 4. Wydatki w \% PKB na technologie komunikacyjne

\begin{tabular}{|c|c|c|c|c|}
\hline Kraj & 2001 & 2002 & 2003 & 2004 \\
\hline $\begin{array}{l}\text { Dawna Unia Europejska } \\
\text { (15 krajów) }\end{array}$ & 3,1 & 3,1 & 3,2 & 3,2 \\
\hline Belgia & 3,6 & 3,5 & 3,4 & 3,4 \\
\hline Czechy & 5,0 & 4,9 & 5,1 & 4,8 \\
\hline Dania & 3,0 & 3,1 & 3,1 & 3,1 \\
\hline Niemcy & 3,0 & 2,9 & 3,0 & 3,0 \\
\hline Estonia & 6,8 & 6,7 & 6,5 & 6,4 \\
\hline Grecja & 4,1 & 3,9 & 3,7 & 3,6 \\
\hline Hiszpania & 3,4 & 3,3 & 3,2 & 3,2 \\
\hline Francja & 2,6 & 2,6 & 2,5 & 2,5 \\
\hline Irlandia & 3,0 & 2,8 & 2,8 & 2,7 \\
\hline Włochy & 3,1 & 3,1 & 3,2 & 3,2 \\
\hline Łotwa & 5,9 & 6,5 & 7,5 & 7,3 \\
\hline Litwa & 4,8 & 4,7 & 4,9 & 4,8 \\
\hline Węgry & 5,9 & 5,3 & 5,7 & 5,5 \\
\hline Holandia & 3,3 & 3,3 & 3,3 & 3,4 \\
\hline Austria & 3,2 & 3,2 & 3,2 & 3,2 \\
\hline Polska & 4,3 & 5,0 & 6,7 & 7,2 \\
\hline Portugalia & 4,5 & 4,4 & 4,5 & 4,6 \\
\hline Słowenia & 3,6 & 3,9 & 4,0 & 4,0 \\
\hline Słowacja & 4,6 & 4,6 & 4,2 & 3,7 \\
\hline Finlandia & 3,1 & 3,1 & 3,2 & 3,2 \\
\hline Szwecja & 3,8 & 3,8 & 3,7 & 3,7 \\
\hline Wielka Brytania & 3,4 & 3,3 & 4,0 & 3,7 \\
\hline Norwegia & 2,2 & 2,0 & 2,3 & 2,4 \\
\hline Szwajcaria & 3,2 & 3,0 & 3,3 & 3,4 \\
\hline Bułgaria & 6,9 & 7,6 & 8,2 & 8,4 \\
\hline Rumunia & 3,9 & 5,0 & 6,1 & 6,6 \\
\hline Turcja & 4,3 & 3,1 & 2,4 & - \\
\hline
\end{tabular}

Źródło:http://europa.eu.int/comm/eurostat/newcronos/suite/ retrieve/de/theme4/infosoc/structur/broad?OutputDir $=$ EJ OutputDir 1969\&clientsessionid=D360CA85303ABFBE603DF35599F5C89C.extraction-anonymous-worker-1\& OutputFile $=$ broad.htm $\&$ OutputMode $=$ U\&OutputMime $=$ text\%252Fhtml\& 
Tab. 5. Udzial procentowy sprzedaży internetowej w całości sprzedaży

\begin{tabular}{|c|c|c|c|}
\hline Kraj & 2002 & 2003 & 2004 \\
\hline $\begin{array}{l}\text { Dawna Unia Europejska } \\
\text { (15 krajów) }\end{array}$ & 0,9 & 1,1 & 2,3 \\
\hline Belgia & - & 1,8 & 1,5 \\
\hline Czechy & - & 2,8 & 1,9 \\
\hline Dania & 1,0 & 1,6 & 4,4 \\
\hline Niemcy & 1,0 & 0,7 & 2,7 \\
\hline Estonia & - & - & 1,1 \\
\hline Grecja & 0,5 & 0,2 & - \\
\hline Hiszpania & 0,3 & 0,3 & 0,4 \\
\hline Irlandia & - & 10,0 & 12,8 \\
\hline Włochy & 0,3 & 0,3 & 1,2 \\
\hline Litwa & - & - & 1,6 \\
\hline Austria & - & 0,9 & 1,0 \\
\hline Polska & - & - & 1,3 \\
\hline Portugalia & 0,6 & 0,6 & 1,3 \\
\hline Finlandia & 1,1 & - & - \\
\hline Szwecja & - & 2,8 & - \\
\hline Wielka Brytania & 1,2 & 1,5 & 2,3 \\
\hline Norwegia & 2,2 & 2,4 & 0,0 \\
\hline Bułgaria & - & - & 1,2 \\
\hline
\end{tabular}

Źródło:http://europa.eu.int/comm/eurostat/newcronos/suite/ retrieve/de/theme4/infosoc/structur/broad?OutputDir=EJ OutputDir 1969\&clientsessionid=D360CA85303ABFBE603DF35599F5C89C.extraction-anonymous-worker-1\& OutputFile $=$ broad.htm $\&$ OutputMode $=$ U\&OutputMime $=$ text\%252Fhtml\&

zjawisko, szczególnie w zakresie rynku pracy (poszukiwanie zatrudnienia, kontakty z pracodawca, telepraca itd.). Mimo wzrostu dostępności do internetu wydaje się, że proces ten należałoby przyspieszyć, również poprzez wsparcie państwa.

- Wprzedsiębiorstwach w Polscejest dosyć powszechny dostęp do internetu, jednakże bardzo niski jest odsetek przedsiebiorstw korzystajacych z łaczy szerokopasmowych. Wydaje się, że tak mała liczba łączy w Polsce może powodować słabszą komunikację i gorsze warunki konkurowania.

- Polska należy do krajów o średnich europejskich wydatkach na technologie informatyczne i wysokich na komunikacyjne.

- W większości krajów UE następuje stopniowy wzrost sprzedaży przez internet, ale, na razie, w całości sprzedaży nie odgrywa istotnej roli.

- Polska należy do krajów o wysokim stopniu wykorzystania internetu przez przedsiębiorstwa do kontaktów $\mathrm{z}$ administracją publiczna.

Z przedstawionej analizy i wniosków wynika, że stała tendencja jest potrzeba rozwoju i dostępu do technologii komunikacyjnych i informatycznych, ponieważ wpływa to na szybkość przepływu informacji. Społeczeństwo polskie na tle krajów Unii Europejskiej nie wypada korzystnie, jeśli chodzi o gospodarstwa domo-
Tab. 6. Odsetek przedsiębiorstw komunikujących się przez internet $\mathrm{z}$ administracją publiczną

\begin{tabular}{|c|c|c|}
\hline Kraj & 2003 & 2004 \\
\hline Unia Europejska ( 25 krajów) & - & 51 \\
\hline Dawna Unia Europejska (15 krajów) & - & 49 \\
\hline Belgia & - & 60 \\
\hline Czechy & - & 75 \\
\hline Dania & 75 & 85 \\
\hline Niemcy & 35 & 36 \\
\hline Estonia & - & 84 \\
\hline Hiszpania & 44 & 50 \\
\hline Irlandia & - & 69 \\
\hline Włochy & - & 65 \\
\hline Cypr & - & 35 \\
\hline Litwa & - & 65 \\
\hline Węgry & - & 35 \\
\hline Holandia & 41 & 47 \\
\hline Austria & 81 & 74 \\
\hline Polska & - & 74 \\
\hline Portugalia & - & 57 \\
\hline Słowenia & - & 47 \\
\hline Finlandia & 89 & 91 \\
\hline Szwecja & 89 & 92 \\
\hline Wielka Brytania & 29 & 33 \\
\hline Norwegia & 65 & 69 \\
\hline
\end{tabular}

Źródło:http://europa.eu.int/comm/eurostat/newcronos/suite/ retrieve/de/theme4/infosoc/structur/broad?OutputDir=EJ OutputDir 1969\&clientsessionid=D360CA85303ABFBE603DF35599F5C89C.extraction-anonymous-worker-1\& OutputFile $=$ broad.htm $\&$ OutputMode $=$ U\&OutputMime $=$ text\%252Fhtml\&

we, gdyż jest niski dostęp do technologii informatycznych i słabe ich wykorzystanie. Znacznie lepsza jest sytuacja w przedsiębiorstwach. Zarówno dostęp, jak i stosowanie technologii informatycznych (wyjątek stanowią łącza szerokopasmowe) nie odbiegają istotnie od średniej unijnej.

Problem, na który w kontekście powyższej analizy warto zwrócić uwagę na szczeblu makrodecyzyjnym w Polsce, to analiza przyczyn niskiej dostępności i wykorzystania technologii informatyczno-komunikacyjnych $\mathrm{w}$ gospodarstwach domowych i wsparcie ich upowszechniania. W odniesieniu do przedsiębiorstw rozważyć można na szczeblu makroekonomicznym wsparcie stosowania łączy szerokopasmowych.

$d r$ Wojciech Jarecki Katedra Mikroekonomii Wydział Nauk Ekonomicznych i Zarzadzania Uniwersytetu Szczecińskiego

*) K. Krzysztofek, M.S. Szczepański, Zrozumieć rozwój. Od spoteczeństw tradycyjnych do informacyjnych, Wydawnictwo Uniwersytetu Sląskiego, Katowice 2002. 